\title{
Type One Error and the Impact of Human Societies on Large Rivers
}

\author{
Béla Borsos ${ }^{1}$ \\ ${ }^{1}$ Institute of Geography, Pécs University of Sciences, Hungary \\ Correspondence: Béla Borsos, Institute of Geography, Pécs University of Sciences, Hungary. E-mail: \\ dioliget@t-online.hu
}

Received: July 7, 2013 Accepted: August 2, 2013 Online Published: August 19, 2013

doi:10.5539/jgg.v5n3p135 URL: http://dx.doi.org/10.5539/jgg.v5n3p135

\begin{abstract}
This paper deals with the management of large rivers from systems theory and human ecology perspective. Natural systems, hierarchy and equilibrium have been widely discussed earlier on, but their relations with human-made structures and modifications on large rivers is a less covered area. One of the key statements in this field is Type One error, the inherent conflict between human-made structures and natural processes. The renewable energy concept, when applied to water resources, has some traps and misleading implications. In fact, renewable sources - including water - can also be depleted if their rate of replenishment is exceeded. Economy-driven river regulations and land use practices triggered a series of events where the system feedback of the river was not taken into account. As a result, the need for yet further manipulations and interference kept on returning, entailing even more and more costs, increased risks and destabilising natural systems. Sustainable river management takes a fresh look at the problem, with historical examples from places like the Carpathian Basin, Mesopotamia or citing recent practices from Thailand.
\end{abstract}

Keywords: systems theory, ecology, large rivers, human ecology, water management, Type One error, system feedback, sustainable river management

\section{Introduction}

Large rivers are complex natural systems consisting of both living and non-living components. Over history, human societies have made repeated attempts to modify rivers in order to take advantage of their resources mainly in the form of water for drinking, sanitation or irrigation. Industrial technology developed to such a level some two to three hundred years ago which allowed for material changes in these natural systems by a number of technical operations. An odd human-technology-nature interaction started as a result. Large rivers globally have become heavily modified and infested with human-made infrastructure, which disrupted their natural cycles of functioning. The natural behaviour of large rivers can best be described with the help of system theory and the same approach may also be useful in understanding the conflict between the dynamics of river processes and the rigid engineering structures imposed on them.

Systems theory is frequently used in theories describing human interactions, trying to provide a way of making sense of events that have happened in the past, and then allowing us to make predictions about what may happen in the future. Human ecology theory is a way of looking at the interactions of humans with their environments and considering this relationship as a system. In this theoretical framework, biological, social, and physical aspects of the organism or society are considered within the context of their environments. These environments may be the natural world, reality as constructed by humans, and/or the social and cultural milieu in which the organism exists. In human ecology, the individual, society and the environment are viewed as being interconnected in an active process of mutual influence and change (Note 1).

General systems theory is a scientific discipline established by Ludwig von Bertalanffy (Bertalanffy, 1968) and advanced by a number of others (Meadows et al., 1972, 1992, 2004; Varela et al., 1974; Capra, 1987 - just to name a few). As opposed to mechanistic and reductionist science, it tries to apply a different approach in the quest to learn about the world, using a concept based on systems, connections and processes.

The emerging new field of human ecology, in an attempt to reconcile natural systems with human made ones, and to make predictions about future human-environment interactions, draws boldly on the findings of general systems theory. One of the findings established by applied systems theory was that the human endeavour is chronically infected with positive feedback loops, actions based on inherently uncertain knowledge and 
examples of the law of diminishing returns. According to most views, these flaws occur due to the fact that nature is chaotic and non-linear, as opposed to the mostly logical and linear human and technical systems (H. Odum, 1994; E. Odum, 1997; Marten, 2001).

In this study, we try to apply general systems theory and Type one error for riverine systems. First, a short review of the main features, principles and processes describes the dynamic system equilibrium and the behaviour of systems and subsystems, in particular in terms of the energy they use. The natural systems are compared to artificial technical systems. Following the theory an analysis reveals the history of human-nature interactions in the life of the rivers, ranging from the deforestation of the upper watershed up to the modern rehabilitation efforts. Examples of sustainable river management are also offered, where Type one error mistakes are avoided. Finally, conclusions are drawn on how to use the insight into the contradiction of logic in both systems for the improvement of human-river interactions.

\section{Systems Theory: A Short Overview}

\subsection{Natural Systems}

The cyclic pattern of natural systems is shown in Figure 1. Living systems are able to capture, transform and store the electromagnetic energy of solar radiation in a series of cyclic processes. The interconnections of these systems are recognized as networks or webs instead of linear chains (Mollison, 1990; Capra, 1997). Deposits from living organisms in various geological times are now known as limestone, coal, mineral oil or natural gas. In fact, these materials are nature's waste from a former stage of Earth history (Lovelock, 1991). It should also be noted that only materials cycle, most of the energy passes through the system as a flux, increasing the system's entropy. Yet the system is readily and abundantly replenished through solar radiation on a long time scale (Postlethwait \& Hopson, 1995, 872).

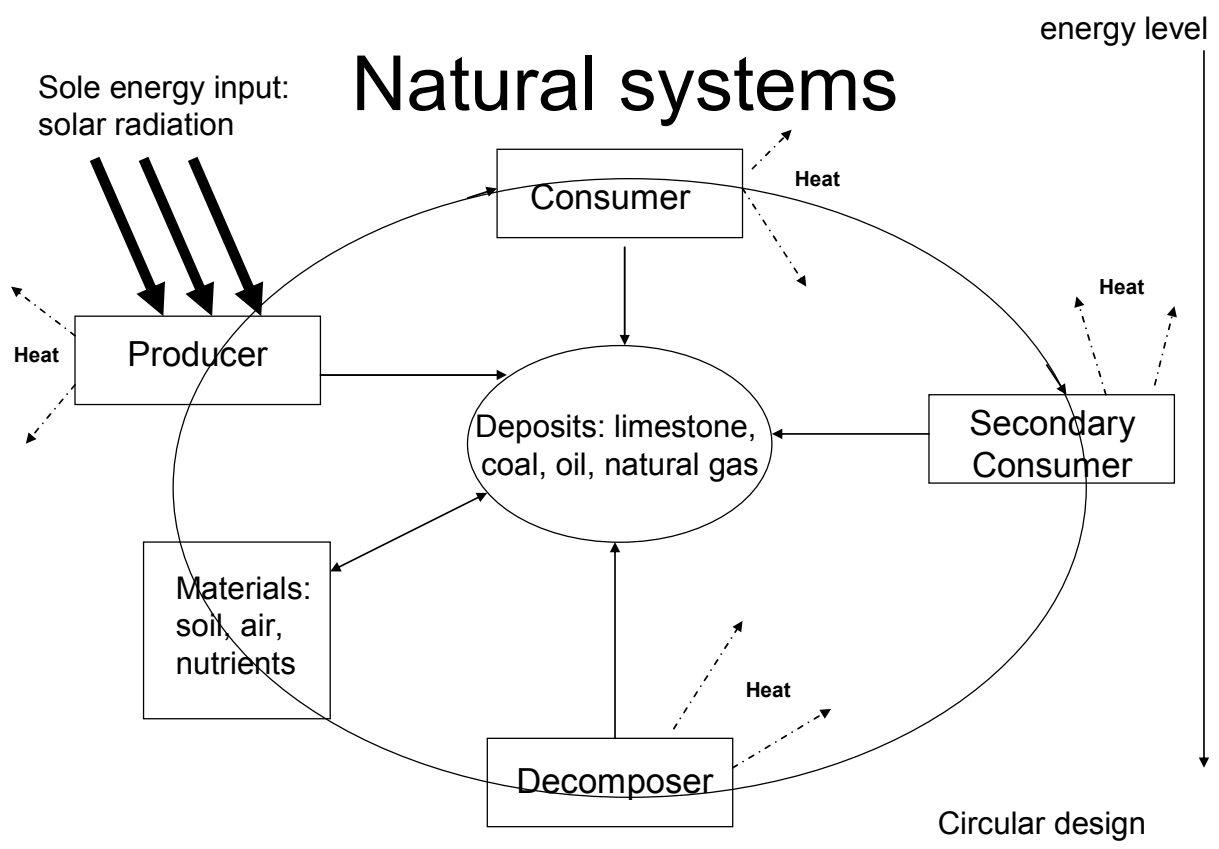

Figure 1. The flowchart of natural system processes

All systems are in dynamic equilibrium with their environment, i.e. the supersystem they are part of. The parts, connections and relationships add up to the structure of the system. Provided a constant flow of energy is available, the structure of the system is remarkably permanent because it tries to preserve the set of connections and relationships which makes it distinguishable as a system: it is conservative in nature (Borsos, 2003). However, the environment keeps on changing all the time, and any system destined to survival will have to adapt to these changes by making adjustments to its own parts, connections and relations over time. This way, external disturbances can be parried and the system itself undergoes a certain development increasing its adaptability, which, in turn, has an impact on the environment, and hence, on the dynamic equilibrium (Gyulai, 2009). Over time, all these changes add up to a different state and different system properties. This process is called evolution, 
whereby the positive and negative feedback loops mutually limit each other's exclusive impacts. Non-living systems tend to increase their entropy - rivers do so by levelling the ground diversified by tectonic movements while living systems increase the level of their organisation, accumulate free energy and reduce their entropy.

Human society is merely a subsystem of the Earth's biosphere, seen in a nested hierarchy by Koestler $(1967,84)$ and Sheldrake $(1987,77)$ Technical systems need extensive external input in the form of energy and raw materials. These resources are almost exclusively obtained from former deposits of living organisms (limestone, oil, gas, coal), through the depletion of non-renewable resources (metals, ores, rocks) or overexploitation of renewable resources (fisheries, forests, agro-ecological systems, water bodies etc.). As a result, runaway positive feedback loops are formed which inevitably chase modern human society into an accelerated development curve - and a trap of system logic.

\subsection{The Renewable Energy Concept}

External energy input is the factor tipping the balance of ecology in human societies. On the time scale of humanity, the sole true external input of energy for all systems on Earth - except maybe nuclear and geothermal energy - comes from solar radiation, now and in the past. Wind, wave, tidal and hydropower are all converted solar energy. The materials such energy is carried by are all cycled. These, the sunlight captured by recent contemporary - biomass and the heat of the Earth's crust are all classified as renewable sources.

But the very term renewable is a relative concept. Resources such as ores, geothermal heat (!) and nuclear fuels are replenished only with the birth of another Universe or planet. Geothermal energy is still considered renewable because of its abundance, while fossil fuels are seen as non-renewable, due to their extremely slow rate of replenishment.

Renewable resources are only renewable as long and when managed sustainably. If used in a rate exceeding their natural replenishment rate, they become overexploited and hence non-renewable. This is in fact that happened to many species eliminated by humans and this is what currently happens to the world's fisheries and tropical forests. The vulnerability of renewable resources, including most energy resources depend on the intensity of use. Intensive use may shift the ecosystem they belong to from one stability domain into another one with different boundary conditions where the rate and potential of renewal is changed and hence, irreversible alterations occur. These irreversible changes are not prevented by the negative feedback loops of supply and demand, which only reflect economic logic and not the biological facts. A decrease in the benefits received upon the increase of intensity of use indicates overexploitation (the law of diminishing returns). When in doubt, it is prudent to follow the precautionary principle (Marten, 2001).

Water resources can also be overexploited. The energy large rivers contain can only be used sustainably when extracted at a rate lower than their replenishment. If a series of dams is built on a large river, the last one will get much less energy than anticipated, especially when other uses - irrigation, drinking water intake - deplete the finite amount of water flowing in it. When the method of exploitation itself interferes with replenishment, for instance in the form of siltation, the resource will not be renewable any more. Also, when there is a climate change entailing the melting of huge glaciers in the mountain ranges of the river catchment, the recycling, renewal and replenishment loop will be interrupted. According to some reports, many of the large rivers throughout the world including the large rivers of the Himalaya, Karakoram and Hindu-Kush mountain ranges, Indus, Ganges and Brahmaputra are all exposed to such risks (Gartner, 2007, UNEP, 2007). River regulation, draining of wetlands and marshes, extraction of water for human needs transfers more freshwater from underground reservoirs into the oceans than recharged through precipitation, which result in drying out of continents: here again, the rate of depletion does not match the rate of replenishment (Horváth, 1993).

Technical systems are fuelled by much higher density energy forms than that of contemporary, renewable sources. They contain carbon in a concentrated form with high calorific value. Carbon is found in a much less dense state in contemporary biomass and absent in other forms of sparse renewable sources such as solar, hydro, geothermal or wind energy. Therefore, on theoretical grounds there is not much hope to replace fossil fuels and to fuel the human system from renewable sources. The enormous volumes of these resources necessary to maintain the current intensity of use make it practically impossible to generate the same amount of energy using renewables. In Three Gorges Dam on the Yangtze River, China, merely to power the 22,500 MW facility two major auxiliary power plants of $50 \mathrm{MW}$ are needed - not to count the energy required for the construction, resettlement, deforestation and a lot of other ancillary operations which, of course, are all covered with the use of fossil fuels (CTGPC, 2007). The seemingly unlimited energy relieves society from the urgent pressure to recycle the material flow. Human systems are thus avoiding the negative feedback loop which keeps positive feedback loops in natural systems under control (Gyulai, 2009). 


\subsection{Technical Systems}

In anthropogenic systems the circular logic of recycling materials - and the energy capturing arrangements - is broken and replaced by a linear one. There is depletion but there is no replenishment of either energy or material resources. On the other hand, in each stage there are new forms of deposits created such as contamination, pollution and waste: low energy, disorganized materials, which do not have much chance of returning to the starting point of the process. Decomposers are completely missing from the system. The system as a whole is irreversible (Borsos 2009). The flow of processes is linear in design, the positive feedback loops inherent in the technical solutions are further reinforced by the dominant growth paradigm of economic theory and in addition to dissipated, irretrievable energy, much of the material input becomes disorganised and unavailable for further processing. This is one of the reasons, why such technical systems are considered to be in host-parasite relationship with the life-supporting systems of the planet (Odum, 1997, 314). Also, one can argue, this inherent flaw triggers the need for constant growth: components of the system must be repeatedly manufactured from fresh resources. Clearly, the contradiction cannot be solved within the framework of the growth paradigm (Figure 2). Water use is no exception to this runaway curve.

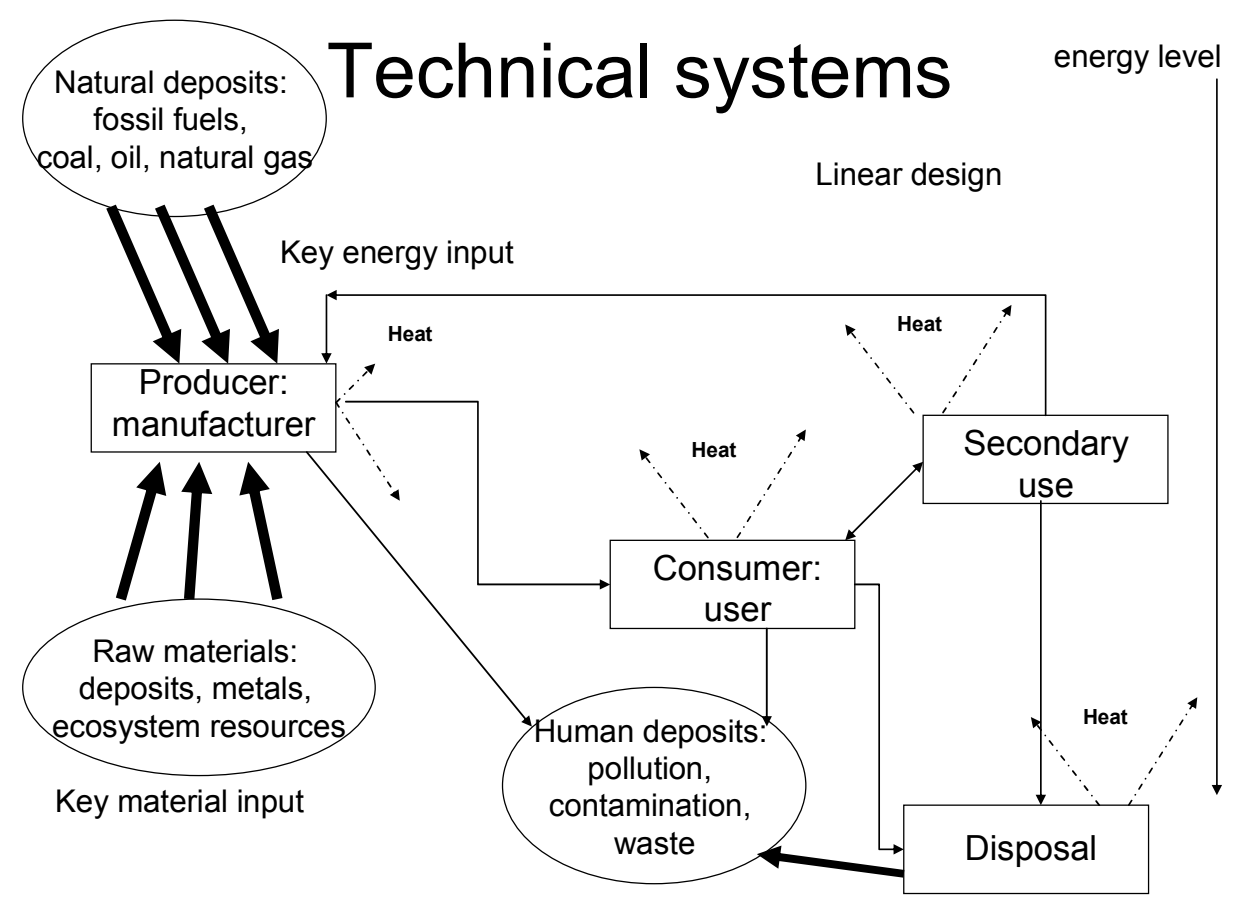

Figure 2. The linear logic of technical systems

\subsection{Type one Error: The Cause of Failure}

The conflict of logic between the two systems results in Type one error, a fundamental concept in human ecology. In this context, the term is used in a completely different meaning than originally proposed by statisticians to differentiate between false negative and false positive samples (Nyman \& Pearson, 1967) and in a slightly different manner later adopted by Mollison to avoid mistakes in our dealings with nature (Mollison, 1988, 58). In our understanding type one error is a kind of positive feedback loop, which follows an impeccable logic known from cybernetics and forms a vicious circle. It arises from the fact that technical and ecological systems have been in constant conflict with each other in the course of human history. It is well known from systems theory that positive feedback loops without the tempering effect of negative ones create a runaway effect bursting the boundary conditions of the system in the end. Having completed such a crash course and collapse, the system will emerge under new boundary conditions which may be quite different from the previous ones (Lovelock, 1979).

In the case of a Type one error, social and technical systems, human societies interact with their superstructure, the natural systems of the planet: ecosystems, biogeochemical cycles and natural resources. During interactions between the social-technological system and the natural systems human needs and population growth usually 
create a problem solved by a technical fix: a linear, technical method. The "solution" has an impact on the natural system which in turn feeds back to the social system, creating an even more complex and comprehensive problem. The new, more advanced solution has an even more detrimental impact on the natural systems, which again feeds back to the social system, and so on, in a positive feedback loop of ever growing dimensions and ever more complex consequences (Borsos, 2009). This triggers more and more intervention into the natural systems at the cost of both natural and human-made system integrity, called the ecological and environmental crisis. In the process, many ecosystem services originally provided by the natural systems free of charge are lost and have to be supplemented artificially, at high cost and - not surprisingly - with the inevitable consequence of creating further problems. Co-evolution and co-adaptation of human social systems and ecosystems - a prerequisite to phase out Type one errors - is no more possible (Marten, 2001).

The underlying philosophical cause of Type one error is that human technical inventions made up to overcome the problem take almost always - and not only since the industrial revolution - simplistic and reductionist approaches without ever considering a holistic system view. They focus only on a single component of the various natural systems which have inherently complex interactions, modify, omit the component or add a new one in a single minded insistence to "solve" the problem. However, natural systems, including ecosystems behave in a complex manner and react to any intervention in a system-like manner. The whole system will be rearranged and new boundary conditions created. Being completely inflexible, technical solutions cannot be adapted to the new conditions and become unfit for the purpose (Borsos, 2003) (See Figure 3).

\section{Type 1 error}

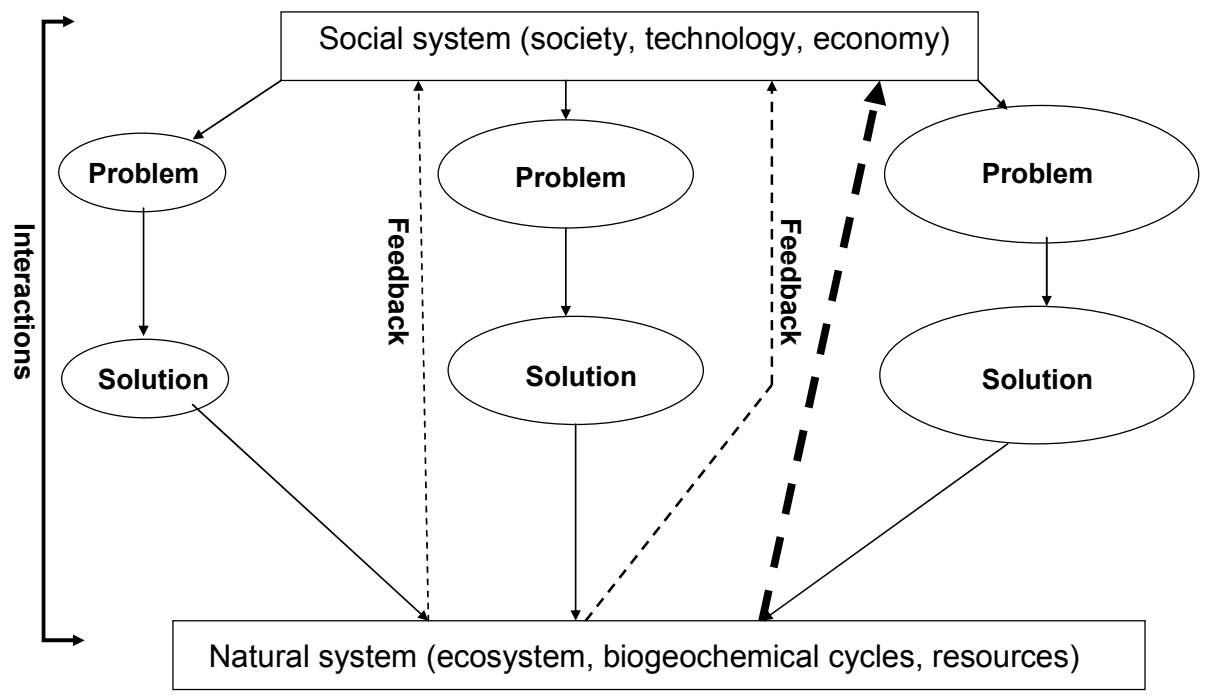

Figure 3. The positive feedback loop of Type one error

\section{Human Societies and Large Rivers}

Illustrative examples to the above referred mechanism include water management practices throughout human history. These are most often associated with the use of water from major rivers. Rivers are part of one of the natural cycles driving the planet's systems which is called the hydrological cycle. The need for very complex water management structures and solutions in modern societies is originated in the differences of functional logic by which natural and technological systems operate. Natural systems have their sole input from solar radiation. This also applies to other than living systems. Although it may seem to be a far-fetched idea at first, ultimately all rivers are driven by solar energy as well. 


\subsection{The Hydrological Cycle}

About $11 \%$ of all water routinely evaporated from the world's oceans as a consequence of the heat generated by incoming solar radiation gets to the continents. To this amount of approximately $3800 \mathrm{~km}^{3}$ water vapour 6300 $\mathrm{km}^{3}$ of water is added, which evaporates directly from the surfaces of the continents and through evapo-transpiration from the vegetation to form rainfall and other types of precipitation, the ultimate source of water in rivers. With the exception of some areas of internal drainage and parts of rainfall stored temporarily in lakes, glaciers or in the soil and in the form of groundwater, all rivers run into the seas. Thus, the water in the rivers is sooner or later recycled just as the organic and inorganic matter in living ecosystems does. And, on the very long timescale, the other non-living material of a fluvial system such as alluvial deposits or rocks is also cycled by erosion and tectonic movements. Rivers basically rearrange things formerly shaped by other processes such as geological forces and long periods of life (Haggett, 2001, pp. 56-63). Thus the processes increasing the entropy of the system - typical for non-living systems - and those diminishing it at the cost of organisation typical for life - are present side by side in river basins.

Under natural conditions, a river - including all its floodplain, valley and wildlife - forms a collaborative, cooperating living system which tries to render itself independent from the external impacts as much as possible. It behaves like a system maintaining its dynamic equilibrium in the same manner as described in the systems theory part of this paper. Hence, the ecosystem developing in the river valley operates to equalize extreme phenomena in the river water regime caused by uneven distribution of precipitation and runoff. Therefore, the health status of a river can be judged from the efficiency by which water level fluctuations and the differential ratio between high and low water are mitigated by the cooperating riverine system. A healthy river is a living system and natural regulation of the water regime takes place through changes in bed morphology, suspended sediment and bedload transport as well as the mitigating effects of the dense riparian vegetation. A specific, diverse landscape is formed in the floodplain where the water carrying capacity of the river is the highest. Due to the dynamic equilibrium however, the parts of the riverine system keep on changing over a larger time span, re-arranging the depressions and higher elevations, the natural levees and ditches every now and then. The hydrological regime is further controlled by the floodplain vegetation which sets up several water reservoirs in the floodplain, thus compensating for the missing natural precipitation (Molnár \& Pásztori, n.d.).

The global water cycle consists of and is supplemented by local cycles which affect only part of the Earth's surface, usually a single river basin. In such local cycles the lower-lying regions of the basin are the source of replenishment water through the action of evapotranspiration by the vegetation. Moisture-laden air is warmed and lifted by the force of solar energy. It is then either drifted to the mountain ranges where, forced to rise, cools down and precipitates again, to feed the head sources of the river system, or falls back onto the same alluvial plain to create runoff into the streams. As an average, $25 \%$ of all rain re-evaporates from leaves, and $50 \%$ is transpired by active metabolic processes of the plants. Thus, forests in the local cycle can actually double the natural rainfall provided otherwise by physical geographic factors (Mollison, 1990, p. 150). Such local cycles drive the water of the Amazon, and the rivers of the Carpathian Basin as well.

Since the invention of organised civilisations, humans did more harm than good to the natural systems they inhabited. One of the first of such interventions into the natural water cycle was deforestation. The interception capacity of the vegetation is easily understood when you make a demonstration plot on a slope with strips where different types of vegetation grow. If you pour the same amount of water at the end of each strip onto the slope, water on the nude surface will run off instantly, just as much as on a harvested field where only the stumps of the cash crop cover the ground. Much less water will gurgle across the straps of grass on a meadow and basically nothing arrives to the bottom where there is a dense shrubby or woody vegetation: the large leaf area of trees and shrubs intercepts water and as long as the entire canopy of the trees is not wetted, not a drop of water will make its way down to the ground. The rich litter and humus on the soil of a forest adds to the water retention potential. This phenomenon is called the 'sponge effect' (Note 2). When trees and other dense natural vegetation cover are removed from the mountain reaches of a watershed, the entire pattern of the water runoff and hence, the water regime of the resulting streamlets, creeks and further down the minor and major rivers will be changed. There will be a much more direct cause-and-effect relationship between rainfall and snow-melt and the flooding of rivers instead of the prolonged and smooth flooding effect experienced earlier on. Additionally, the lost forest cover enhances erosion which causes sedimentation downstream. In the Alps, large scale deforestation at the end of the $18^{\text {th }}$ century increased erosion processes, sediment input and bed load accumulation which resulted in river bed aggregation so severe that the formerly braiding mountain reach of the Rhine (Alpenrhein) and its tributaries had to be straightened (Jungwirth et al., 2009). 


\subsection{River Regulations: Round 1}

There is a contradiction between the dynamics of human society and natural systems. It can be demonstrated in the history of large rivers. The trap caused by Type one error in river management can be shortly summarised in the following pattern:

1) River regulations in the first place were triggered by

- increased need of land for cash crop agriculture,

- more severe floods due to deforestation and

- the requirements of navigation on the lowlands.

2) The technical solution was to build earth embankments and dikes. This resulted in

- reduced water carrying capacity and

- rising floodway levels, together with

- incised river beds creating both

- drought at times of low water levels,

- $\quad$ sudden rises in water flow (more intense fluctuations) and

- even more floods which, in turn, were intended to be retained by

3) Lowland dams. As usual in lowland dams:

- Siltation, eutrophication, drainage problems, waterlogging and erosion usually take place due to the fact that a low stage river runs on sedimentary bedding, which is permeable and has low resistance against the power of water.

- The resulting situation threatens ecosystems and drinking water reservoirs.

4) Again, a technical solution is needed in the form of a number of structures to replenish water and restore river life. This means, that currently, since intensive river management began, we are in the fourth cycle of Type one error.

According to the modern theory of green history, human societies in their development create technical innovations which increase the ecological carrying capacity of their environment on a temporary basis (Ponting, 1991). However, humans do not recognise the transient nature of this improvement and start to reproduce in the ' $r$ ' strategy manner known from ecology, i.e. recklessly increasing the size of their populations without any limitation of the number of offspring as long as the boundary conditions of the improved environment allow (Townsend, 2000). When population pressure grows again to an intolerable level, there is a greater chance for yet another invention which then relieves society from the pressure. In modern organised societies this mechanism is accelerated by economic factors such as converting subsistence livelihoods into cash economy.

Essentially, this is what happened to the rivers and triggered the vicious circle of Type one error in river management. When, first in Europe, market economy became the dominant organising paradigm in modern societies, markets triggered a demand for food which could be sold at a profit. In response, landlords started to grow cash crops such as wheat and maize. However, there was not sufficient land well suited for growing intensive cash crops. Action had to be taken to increase the size of arable land at the cost of other types of land use such as forestry or marshland. At different points in time, among different circumstances, but for most part the main incentive for river management efforts was the quest for ploughland. Flooded areas did not support intensive crops like wheat, potato or maize, later on sugar beet, rapeseed and a number of other industrial plants.

Another line of market economy - remember: human societies create problems during their development in connection with their physical environment - was the need for transport. Markets are concentrated around large towns and cities, while most of the products they seek to sell are not. Transport routes before the discovery of internal combustion engines were very much restricted in terms of speed and capacity, let alone the means of transport. Therefore, in Europe of the $17^{\text {th }}$ and $18^{\text {th }}$ centuries navigation attracted much attention. Barges were hauled along the major rivers and people committed everything to improve the conditions for navigation and to extend the season.

The fall of previous ingenious river management systems into disrepair such as traditional floodplain and marshland economy, aggravated by the stripping of land from its forest cover in the mountains caused rivers to flood in an unprecedented and dangerous manner. At the same time, due to the increased population, the need for 
arable land and the resulting scarcity of space, people started to settle on lower-lying land prone to floods. Obviously, such areas were exposed more often and more severely to damaging water surges.

All these factors tended to create a situation which cried for a technical solution. The solution proposed by contemporary technocrats - not knowing or disregarding the basically arid nature of lowland river floodplains was to get rid of what they thought was excess water. There were three handy measures to do so:

- reducing the length of the river, thus letting water through flood risk areas more quickly. This was achieved by cutting through bends of meandering rivers, straightening their courses and increasing channel slope across alluvial lowlands;

- limiting the size of area inundated by floods and dissecting natural floodplains into two, permanently separated sections by way of constructing artificial levees and dikes: the floodway or active floodplain within the two opposite embankments in a certain distance from the banks along the river and the so-called "protected" side, the inactive (morphological) floodplain, which would have been inundated by regular floods had it not been for the flood control works;

- draining the inactive floodplain - thus relieved from the burden of annual floods - of the remaining stagnant water.

The solution, as happens all the time with Type one error interventions, seemed to work well at first. The land was drained, floods contained and cash economy flourished. At high costs, because poverty and disempowerment of local inhabitants increased. They were deprived of their subsistence farming methods and forced into a market economy they utterly disapproved as evidenced by ethnographers and historians (Andrásfalvy, 1973; Rácz, 2008).

\subsection{Consequences: System Feedback}

Over the centuries passed since the first river regulation projects, the stability of the biologically diverse, rich fluvial ecosystems has been lost due to the large-scale flood control programs, the introduction of intensive agricultural production and extensive drainage projects. Since at the same time the previously experienced heavy deforestation in the mountain catchments of almost all major rivers were now accompanied by sealing surfaces and changing land use patterns, the concept itself of conducting water flow downstream in the main riverbed became a threat.

\subsubsection{Antagonistic Effects: Incision and Siltation}

Water ran more rapidly in the regulated river bed, where due to the shortened meanders and bends cut through, it incised its own bed at times of low water. On the other hand, the river filled up the high water bed between the embankments (active floodplain or floodway) with sediment during high water, because there was not enough space now to spread the suspended load over a large area across the former floodplain (Cosgrove \& Petts, 1990). It had to rise vertically instead, leaving all bedload, suspended sediment and flotsam and jetsam behind in the floodway (Horváth, 1993). The two kinds of effect - erosion in the river bed and sedimentation in the floodways - resulted in lowering the low water river bed and rising of the overall height of the bottom between the dikes (Kajner et al., 2009). These antagonistic changes had several paradox implications. At times of low water the incised riverbed acted as a drain, drawing water from the groundwater table below the lowlands which was formerly replenished by the same river. In addition, water was retained in the area for a shorter period of time because channel slope was increased and therefore it ran down the bed more quickly (Schabuss \& Schiemer, 2009). As a result, drought was aggravated during the summer seasons on the lowlands in an era of intensive agriculture, when water for high yield crops was needed very much. On the other hand, the floodway started to be silted up with an increased amount of sediment transported by the river from higher reaches. The cross-section and hence, the water carrying capacity of the artificially narrowed floodway was reduced while the pattern of water flow also changed: floods arrived more rapidly due to the lost sponge effect in the mountains and rose more rapidly due to the lost floodplain in the lowland. In other words, reverse effects emerged unintentionally beside the achievement of the first priority: increased amount of land. One has the feeling that responses provided by technofix solutions have inevitable consequences which either render the achievement of the very same objective impossible for the sake of which they were devised in the first place, or bring back the same or similar problems through the back door (Tenner, 1996).

\subsubsection{Drought and Excess Water: The Temporal and Spatial Patterns Lost}

However, the newly drained land was not much of use if not protected from the two paradox effects: drought in high summer and destructive floods mostly in spring or early summer. In theory, what happened was that technocratic approach made an attempt to propose supplementary solutions first, constructing irrigation schemes 
and transfer pumps to replenish water in the fields, and increasing the height of the flood control structures. However, both solutions have their inherent technological limits and could only be considered as a solution for a very limited amount of time: being a positive feedback loop at work, which is not at all interrupted by these supplementary, auxiliary attempts, sooner or later irrigation becomes prohibitively costly and earthen dikes can not be raised any longer. As an additional consequence, navigation was not improved at all: the low season saw the formation of shallow fords and under flood conditions shipping became more dangerous, ports were exposed to extreme water level fluctuations. The former problem could be overcome by yet another intervention, the so-called low water river regulation (dredging and the construction of bank heads, groins), while ports had to be dredged and artificially strengthened.
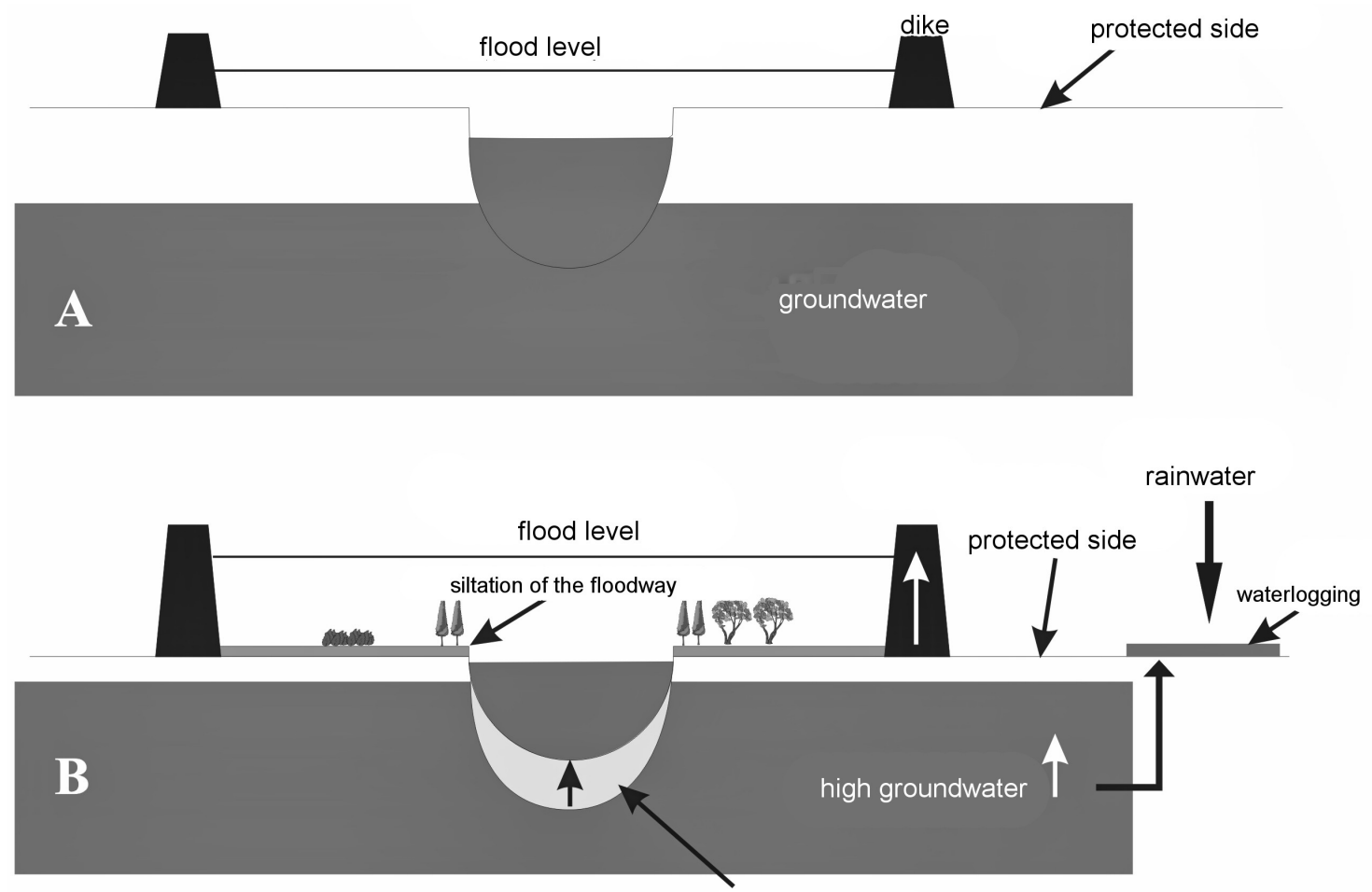

bedload

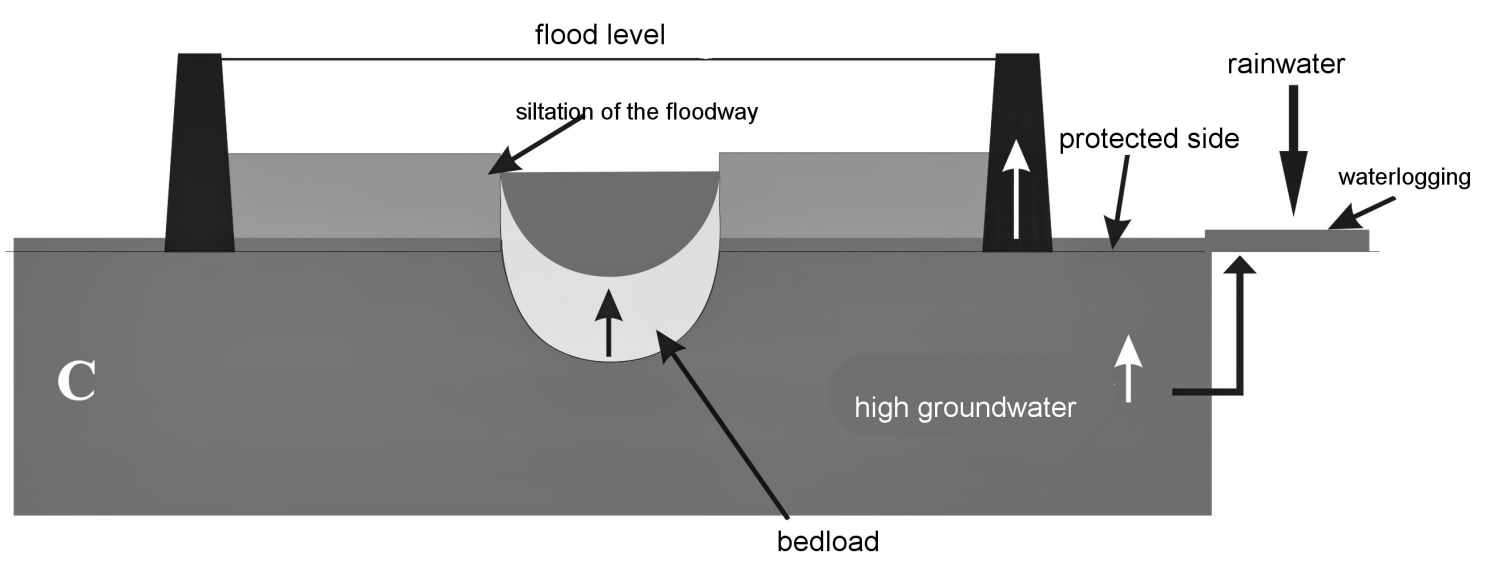

Figure 4. System feedback of river regulations: A: Dikes cause the high water to stay within the floodway, but at a cost of hydraulic pressure building up relative to the protected side. B: Siltation of the floodway rises flood levels further causing excess water appearing on the protected side. Incision of the river bed draws groundwater table during low water season. C: The process goes on in a positive feedback loop until earth embankments can not be elevated any longer (Design by Tamás Bánvölgyi, 2003) 


\subsubsection{Positive Feedback: The Never-Ending Story}

The aforementioned processes are all governed by positive feedback mechanisms and are examples of Type one error. The ever rising floodwater levels obviously had their consequences: higher and more dangerous floods burst the dikes occasionally causing much more damage on the now lower lying "protected" (inactive) floodplain outside the levees than before. Changing climatic patterns and torrent rain in the mountain catchments resulted in ever increasing record flood levels with disastrous consequences in some years (Bodnár, 2009). High water in the elevated river bed also has an impact on groundwater, causing waterlogging of the productive land near the river on the inactive floodplain during the winter and spring season, which turns into serious droughts during summer, when, due to climate change less and less rain falls. The dynamic equilibrium of the river as a system and its surrounding environment has been broken on two accounts: the internal regulatory mechanism could not effectuate the necessary changes in parts, connections and relationships any more and the adaptability of the system to external impacts (climate change) was utterly lost. The processes are summarised in Figure 4.

\subsection{Dams and Reservoirs: Round 2}

The impeccable logic behind a Type one error in case of a river is that previous water management interventions such as cut of bends, low level river regulations, flood control measures, narrowing floodways, eroded riverbeds solicit more and more (and more and more costly) interventions in the same vein because the situation due to the positive feedback becomes untenable after a while. Therefore, the next round in intensive river management is the proposal of artificial water retention: dams and reservoirs.

By impounding the river - the argument goes - you gain a number of beneficial ecosystem services otherwise lost. Nobody seems to remember that most of these services were delivered by the same river once free of charge and in particular without the need to deploy any high- tech and capital-intensive technology.

There is no shortage in listing the benefits of large dams. They

- will improve the navigation route;

- allow electric power generation using a 'renewable' source;

- assist flood control;

- provide the so much desired irrigation water for agriculture;

- have transport advantages (the dam may serve as a bridge, for instance);

- may promote industrial activities related to inland waters;

- encourage recreation and tourism;

- allow the extraction of drinking water in arid areas with no or scarce groundwater endowment;

- boost fishing (Goldsmith and Hildyard 1984)

Intensive approaches to river management resulted in some 45,000 large dams all around the world by the year of 2000 (WCD, 2000). In principle, there is a considerable difference between dams built on the bedrock along mountain reaches of high- gradient rivers and lowland dams built on floodplains where the river runs on its own alluvial sediment and has a minimum slope. The two types of dams raise different problems, but we focus primarily on lowland dams here, for these are the proposed technical solutions for the problems emerging from regulated lowland rivers.

\subsection{Consequences: System Feedback}

Permanent concrete dams create a constant barrier in the way of the river, which, unable to flow freely, starts to fill up the valley behind the dam, thus inundating formerly flood-free areas and rising as high as the dam or its spillways are. A system theoretical consideration with respect of lowland dams is the relationship of the human structure to the boundary conditions of the receiver system, i.e. the river and its environment. Mountain dams fill up the natural valley of the watercourse, while at low stage rivers, which run on alluvial sediments, and, hence, meander or create braided structures, the construction of a dam inevitably requires the change of the boundary conditions of that river: the entire impoundment area has to be built artificially, the water regime of the fluvial system is disrupted in the Type one error logic and the related ecosystem becomes completely modified. As a result, predominantly natural boundary conditions become predominantly artificial boundary conditions in the course of a single qualitative change (Ferencz, 1989). This change, however, has far-reaching consequences upstream and downstream of the structure itself, while other parts of the supersystem (the mountain range of the watershed, human activities or climate change) conflict with the altered subsystem in many ways. Water, as a liquid, requires a vessel for containment. This vessel is the riverbed, which may be susceptible to changes in the 
external boundary conditions. Also, building of such an extensive, large scale structure always requires significant non-renewable resources in the form of fossil fuels, stone, concrete, steel and other materials (Borsos, 1989). Also, mountain dams have a much more favourable surface/volume ratio and, therefore, lesser relative water loss through evaporation than lowland dams. These differences however only apply to the extent of certain types of unintended consequences only, mountain dams are ultimately just as much inherently prone to the Type one error as lowland dams are.

\subsubsection{Adverse Effects}

The adverse social and environmental effects of large lowland dams have been extensively studied and documented (Goldsmith \& Hildyard, 1984; WCD, 2000). Throughout the world, large scale river construction projects tend to have the following consequences:

- loss of land and wildlife upstream

- loss of silt and fertility downstream

- river bed degradation downstream

- water losses through seepage (poorly constructed embankments), evaporation (in hot climate) and transpiration (aquatic weeds) exceeding gains

- $\quad$ spreading of waterborne diseases (malaria, schistosomiasis, filariasis, river blindness, etc.)

- pesticide pollution and the destruction of fisheries, resulting in net loss of protein

- risk of earthquakes and other causes which may result dam failures

- salinisation and waterlogging

- promotion of cash crop economy and urbanisation

- sedimentation of the reservoirs

- loss of forests in reservoirs

- submergence of inhabited areas and the need for resettlement.

From the system theoretical point of view, these consequences arise from the fact, that dams and in particular dams with hydropower schemes cause the loss of free-flowing river sections, change the discharge conditions and the bed load regime, as well as the hydromorphological dynamics and structural heterogeneity of the water course. Dams result in channel degradation downstream, further disrupt connectivity between the river and the floodplain, including groundwater reservoirs underground, interrupt the river continuum, and in many cases divert water from the original bed, leaving only residual water flow behind; peak operation methods cause unnatural high surges, flushing impoundments and reservoirs and eroding subsoil down to the bedrock downstream (Jungwirth et al., 2009). The costs and benefits related to large dams and hydropower schemes is summarised on Figure 5. 


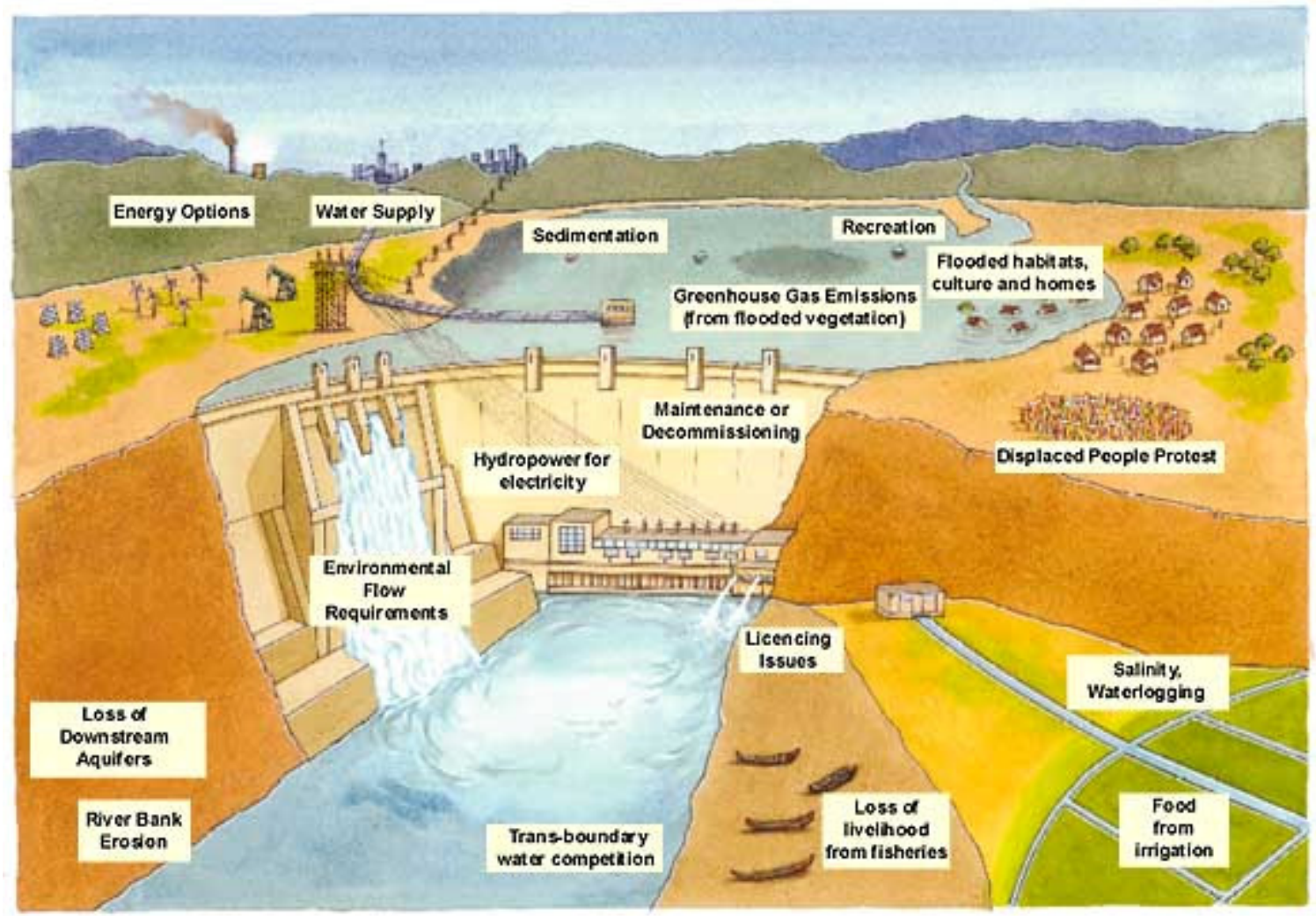

Figure 5. The pros and cons of large hydroelectric dams (Source: WCD report, 2000)

\subsubsection{Examples}

Being a next round of Type one error, such consequences can in fact be predicted with confidence. Let us first see the double-faced problem of siltation and erosion. In middle stages and low stages of rivers the terrain is shaped by the river using bedload entrained from upstream bedrock reaches. Therefore, under conditions of lower course rivers these processes are quite obvious. But even in the case of dams built on bedrock, such as the Hoover Dam on Colorado in the US, the same processes are at work - only not so spectacularly. On one hand, the reservoir is being filled up with sediment which cannot pass through the barrier. In fact, in the case of Hoover another dam, Glen Canyon Dam had to be built upstream to catch the sediment input into Lake Mead, the reservoir artificially created by Hoover Dam, to prevent it from silting (Mickens, 2006). Earthquake hazard is also created by filling up Lake Mead. This led merely shifting the problem upstream and now Glen Canyon Dam is threatened by the one hundred million tons of sediment load accumulating in Lake Powell, its reservoir since the completion of the dam in 1964. Built on relatively soft sandstone bedding, the failure of Glen Canyon Dam due to overtopping would produce catastrophic flooding with unprecedented flood depths and discharges all the way to Lake Mead and Hoover Dam (Haskell, 2003). To complete the picture, Hoover Dam itself is also "eaten up" slowly by the Colorado river (Worster, 1984).

The sediments trapped in the reservoirs are missing downstream: fertility ensured for soil in the lowlands by recurrent floods depositing the suspended fine sediment they carried is no longer there to replenish nutrients for agriculture. In the case of the Nile, where the Aswan High Dam was built to store water throughout the year, many of these problems surfaced as 'secondary effects'. For ages, fertility of Egypt's soils was ensured by the annual floods of the Nile. Damming the river caused the steady deterioration of fertility in the river valley, because of the Nile being unable now to deposit vast quantities of nutrients on agricultural land on the floodplains, where soil is gradually depleted by modern agriculture and local brick factories (Lavergne, 1984). While the dam boosted a thriving fishing industry within Nasser Lake, the reservoir, it had disastrous effects on marine fisheries (el-Sayed et al., 1995). The downstream erosion causes the retreat of the delta, making it more vulnerable to predicted sea level rises due to global warming (Frihy, 2003). 


\subsubsection{Ecosystem Services Lost}

However, siltation upstream and erosion downstream are just two of the major impacts caused by the Type one error of disrupting the adaptive capacity of the riverine ecosystem. Shallow impoundments on lowlands have other serious consequences as well. The boomerang effect of large scale dams can best be demonstrated by a number of functions which have to be artificially replaced by the same human society which had enjoyed the benefits of a free-of-charge service provided by the living river. Most probably no economic cost-benefit analysis would justify the construction of large dams should a full accounting have been made including all such 'auxiliary', 'secondary' and 'consequential' losses and effects.

An excellent example is the issue of wastewater treatment. As long as a free-flowing river is the receiver of the sewage generated by its riparian cities, the self-purification capacity of the riverine ecosystem and in particular of its aquatic communities is able to cope with the contamination to a certain degree. Given sufficient time, oxygen, sunshine and flow velocity, a high amount of polluted water can be effectively purified or at least contained in less toxic forms (such as the stalks of reed-beds). When a river is regulated, its banks "developed" by riprap or paved quays, it will become deprived much of its aquatic communities, and when it is dammed, water flow in the reservoir would be very slow, dissolved oxygen content of the water reduced and aerobic microorganisms, responsible for breaking down the organic matter in sewage, replaced by anaerobic ones. The increased phosphate levels nourish algae and other photosynthetic cells, causing severe eutrophication. No wonder that most reservoirs in densely populated areas suffer from eutrophication and the reduction of organic matter load in the river is of paramount importance (UNEP, 2009).

Another common problem is drinking water. Under natural conditions, many of the large rivers provided the plains with good quality drinking water through a natural filtration process by which seasonal inundations of the floodplain allowed river water to seep through the loose gravel or sand subsoil of the alluvial plain, annually replenishing the underlying aquifer with good quality filtered drinking water. Humans had nothing to do but to drill horizontal wells on the riverbanks with perforated pipes - the bank-filtrated wells - and pump out the ready-made freshwater. In the area of large dams, this ecosystem service is lost or seriously impaired. For a perceived economic advantage a genuine ecological service is sacrificed. For the very same reason, i.e. slowing of the water flow in the reservoirs, the bottom of these huge artificial lakes becomes clogged with silt and thus the infiltration of river water into the underlying groundwater reservoirs stops. Downstream, where stream power erodes the riverbed, and strips barren the gravel layer formerly acting as a natural filter, the same polluted water may penetrate the pristine high quality groundwater bodies contaminating them for thousands of years (Deák et al., 2001; Novak, 2009).

The alluvial soil on which lowland rivers flow is permeable. Communication between unconfined groundwater and river water is disrupted. The hydrostatic pressure of the water in the reservoir seeks other ways of balancing the levels in the manner of intercommunicating vessels. The earthen embankments of a reservoir and the upper layer of the underlying ground will allow water to percolate - if not to the groundwater reservoirs, then onto the surrounding agricultural land. This is how land becomes waterlogged around large dams and reservoirs. It has to be drained at high cost through seepage canals built beyond the embankments and transferred back to the river by energy- intensive pumping.

\subsubsection{Business as Usual: More of the Same}

The impeccable logic of type one error claims again the technical solution for these problems. Riverbed degradation and excess water level fluctuations sweeping away riparian habitats can be mitigated by adding one more dam downstream to impound water back up to the impact area of the upper dam. The logic triggers a chain reaction and, as actually seen in many large rivers worldwide, one dam after the other are being built into the rivers in a cascade-like fashion. Obviously, the process has to end somewhere: at the river mouth. Pending on the situation, the last dam causes river deltas to retreat or estuaries carved even deeper than before. In either case, coastal erosion occurs. According to the calculations of the US Geology Survey, 67\% of all sediment is missing from the Mississippi river by the time it reaches the Gulf of Mexico. Nearly 2000 square miles of land had vanished by the turn of the millennium and one third of Louisiana state will be gone by 2050 if the rate of erosion is maintained (ENS, 2003).

\subsection{Mitigation of System Feedback Consequences}

\subsubsection{Granulometric River Restoration}

Measures taken to mitigate secondary effects of large dams and hydropower schemes are currently being reviewed in Europe (Korze-Vovk et al., 2009). Most of these pilot projects focus on ensuring more adequate 
bedload transport based on clear identification of the deficit caused by the disrupted equilibrium of the entire river basin as evidenced by the appropriate geomorphologic studies and assessments. What was a natural process before must be artificially provided now, in many cases through the deployment of a serious amount of input. One task to be completed is the removal of sediment from the reservoirs and another to supply the necessary bedload to downstream sections. On the Rhône River, for instance, a master management plan introduced the compulsory sediment transport for weir and dam operators. The gravel extracted from the reservoirs has to be reintroduced immediately downstream of the weirs to preserve sediment transfer. Sometimes the remaining sediment carried by the river is insufficient to prevent or mitigate further incision of the riverbed, therefore external gravel and sand input is needed. On the Rhine River below the Iffezheim barrage an annual average of 170,000 tonnes of sand and gravel is dumped into the river bed from barges to compensate for trapping the bedload by upstream dams (Piégay \& Rinaldi, 2008), and a similar approach is taken on the Danube after the installation of the Freudenau hydropower plant where each year approximately $300000 \mathrm{~m}^{3}$ gravel has to be added to the river in order to prevent fatal erosion of the Danube Marshland Natural Park downstream. The 30 to $70 \mathrm{~mm}$ pieces are actively mined in nearby quarries and supplied to the river to improve the navigation route. The method is aptly called the 'granulometric bed improvement' (Kordina \& Hanish, 2004; Christian Baumgartner, personal communication, 2009).

\subsubsection{Restoration of Lost Ecosystem Services}

Disciplinary boundaries make it even more difficult to predict the consequences of a technical intervention into a natural system. In the case of large rivers for instance, water engineers have not been taught any ecology for a very long time. Accordingly, the lessons had to be learnt the hard way. Completed river projects are now under consideration for reconstruction in order to be able to restore the ecological flow necessary for the maintenance of aquatic life and the connections between various elements of the local ecosystem. In the process, an indicator of hydrologic alteration (IHA) was developed to assess the level of alteration in flow regimes caused by anthropogenic pressure to set a benchmark for restoration efforts (Richter et al., 1996, 1997, 1998). The resulting calculations underpin the so-called environmental flow requirements, the amount of water needed to preserve life in the river.

\subsubsection{Hydropeaking and the Restoration of the Ecologically Necessary Flow Patterns}

The technical mind finds ingenious ways to exploit the full potential of an easily controlled electricity generation method like the utilization of hydropower. Hydropeaking or more appropriately the peak operation method is a specific type of hydrological alteration usually occurring at time scales smaller than one day (therefore not recorded by daily average flow monitoring). Hydropower plant operations concentrate the production of electricity by releasing the impounded river water from the reservoir when the price of the energy is the highest (usually during the day), whereas water is held back when it is the lowest (usually at night). The result is an artificially and extremely pulsating stream flow regime. The shift between minimum and maximum discharge usually occurs within a very short time-span, typically between 15 and 30 minutes, depending on the characteristics of the flow (Zolezzi et al., 2009). The impact on biological communities is usually dramatic, since aquatic organisms do not have sufficient time to react to changes so sudden. The pulses influence the distribution and quality of physical habitats and, consequently, have adverse impacts on the living conditions of organisms: during electricity generation periods intense discharge leads to hydraulic effects such as fluvial erosion or to intensive drift and active flight behaviour of organisms. After peak generation organisms can get stranded on land or isolated in pools, where the decreasing concentration of oxygen can cause them to suffocate. This effect is particularly noticeable in river stretches whose natural morphology has extensive zones of shallow water (Korze-Vovk et al., 2009). As opposed to the well-studied field of hydropeaking impact on the ecosystem, only a very limited amount of experience exists in applying mitigation solutions, usually involving loss of plant peak load capacity. The scarce win-win examples, involving coordination among different plants in interconnected networks, seem to apply to small to medium scale structures only and not to large dams (Moser, 2007).

\subsubsection{The Ultimate Destiny of Lowland Dams}

Ultimately, all lowland dams are destined to siltation, i.e. total fill-up as it had been observed in many places throughout the world. Smaller dams obviously fill up more rapidly, but sooner or later large dams also inevitably follow suite (Chanson, 1998; Chanson, 1999). Additional problems arise when diverted water fails to reach the receiver water body, causing serious environmental catastrophes such as the shrinking of the Aral sea due to extraction of irrigation water from the Sir-dar'ya and Amu-dar'ya rivers (NASA, 2009, see Figure 6) or depletion of the Colorado by the time it reaches the Californian Bay in Mexico (Morrison et al., 1996). 


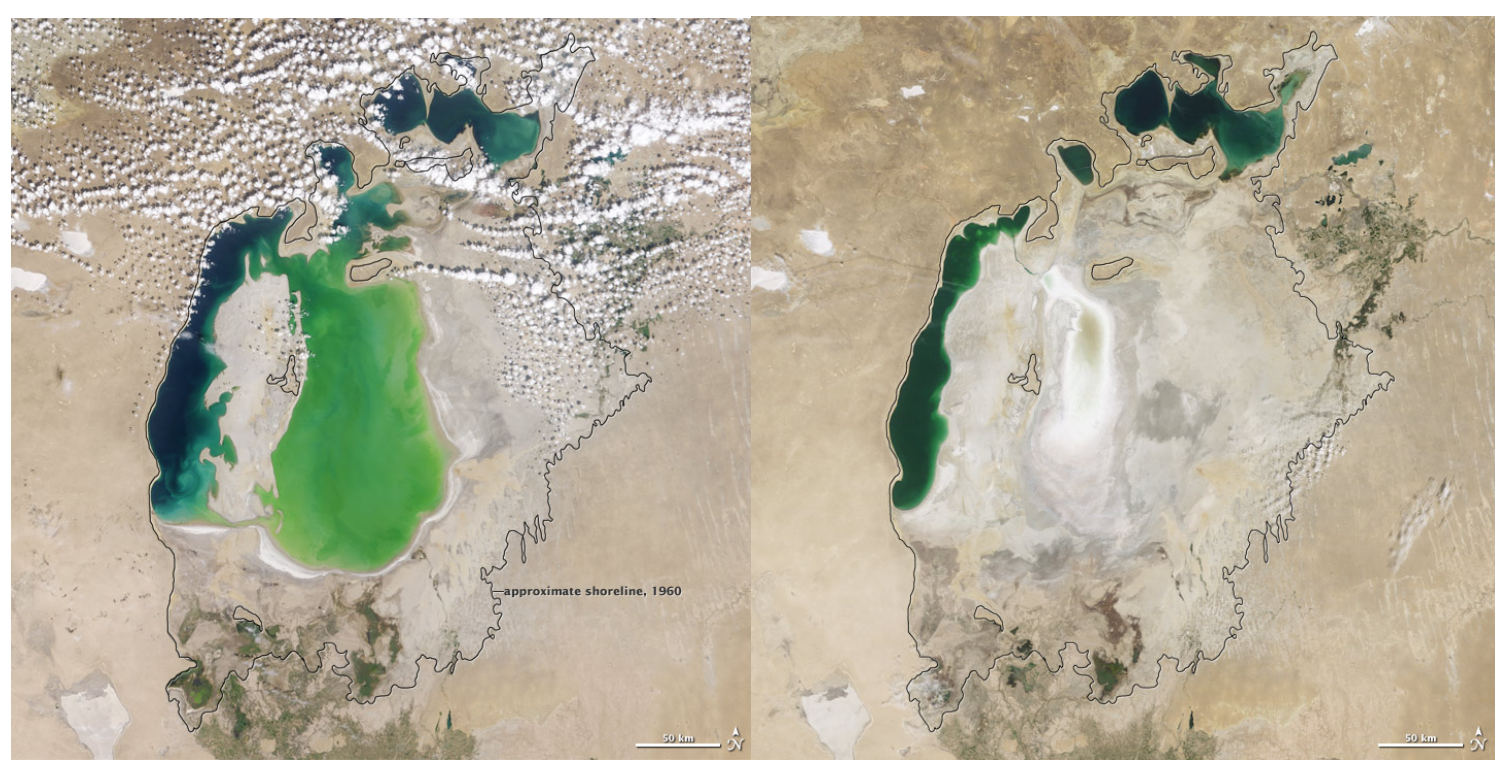

Figure 6. The vanishing Aral sea. Evaporation takes its toll on the Central Asian lake. The grey contour shows the original shoreline in the 1960s before the construction of the large irrigation projects, the picture on the left was taken in 2000, the one on the right in 2009) (Source: NASA, Earth Observatory 2009)

\subsubsection{Maintenance and Operation}

Although this aspect is not in the focus of the present paper, large dams are chronically exposed to serious maintenance and management problems and, during operation, they usually have to face a lack of appropriate funding (Goldsmith \& Hildyard, 1984). Decommissioning of large dams may also create problems. There is only very limited experience available to proper demolition, although large dams are certainly very dangerous when becoming unstable for whatever reasons (McCully, 2009). The European scene is even less exploited than the possibilities in other areas and only small dams have been removed to date (Epple, 2000). When interventions into the life of the river are presented in chronological sequence, it can be seen that less and less time elapsed before yet another intervention became necessary in the vicious circle triggered by the first Type one error (VITUKI, 2009).

\section{Type 1 error: the river}

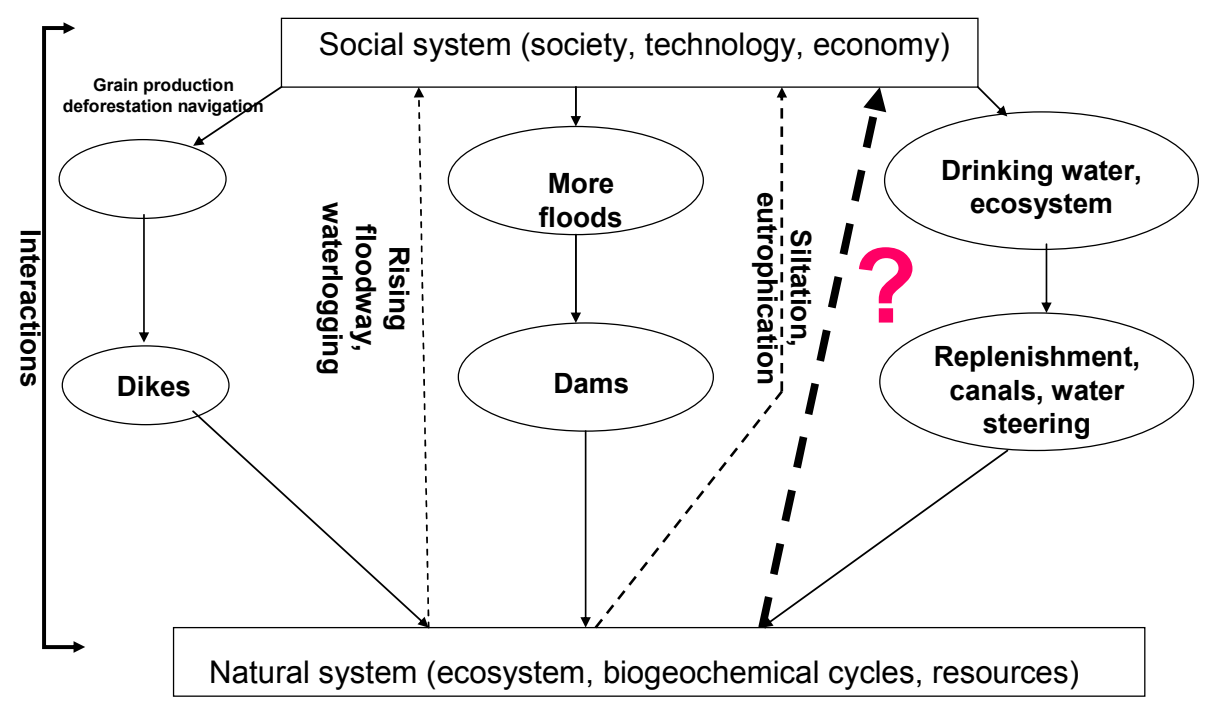

Figure 7. The management of large rivers is also exposed to Type one errors 


\section{Sustainable River Management in the Light of Type One Error}

\subsection{Principles}

Having had an insight into this inevitable mechanism, the question emerges how to overcome such a situation by intelligent design of social systems and not by „commanding” natural ones. There are some considerations which need to be taken into account if a sustainable human system is to be set up. Sustainable design may theoretically overcome the problem of technical systems, provided some design rules are observed, designers and builders avoid overexploitation of ecosystems, oversized structures, resource waste or type one errors and apply local systems, circular design patterns, constant feedback, renewable resources, careful planning with flexibility and adaptivity at the appropriate time scale and physical size, under cybernetic social and technical control. Bioregionalism, for instance, based on river watersheds which are the most commonly defined boundaries of bioregions (Sale, 1991), is one of the design concepts and systems offering a simple principle: it turns the issue upside down and instead of considering social, human needs (and follies) as unchangeable, it sets up ecologically sound human systems by taking the locally available resources as the guideline for development and adapt human presence to them.

In the design system called Permaculture, cybernetic control (negative feedback loops) is introduced as the basis of regulation, just like nature does in ecosystems. A carefully balanced equilibrium of positive and negative feedback ensures healthy development. Planning is made in four dimensions, anticipating the future climax and taking account of the successions as well as the connections between the natural and technical elements in the system. Zones and sectors, sites for structures are defined according to the existing natural conditions (Mollison, 1990). This way, theoretically a really sustainable human system may be developed which is in line with the negative feedback loops of natural systems (Figure 8). River ecologists list the necessary components of a holistic, integrated river management concept as follows: river systems have to be considered as multidimensional landscapes of highly dynamic nature with complex connectivity and heterogeneous habitat complexes, where disturbances play a key role in the shifting mosaic state of a system with outstanding high level of biodiversity (Jungwirth et al., 2009). In addition, a certain amount of space is absolutely necessary for the river to move freely. The lateral dimensions of such spatial requirements are different for morphology, hydrology and ecology, and cannot be violated by the anthropogenic spatial requirements if long term sustainability and adaptability is to be ensured (Hauer et al., 2009). The potential to restore river connectivity in the framework of an integrated water resources management concept using these principles along the Hungarian reach of the Tisza River has been discussed by Borsos and Sendzimir (2013).

\section{Sustainable river management}

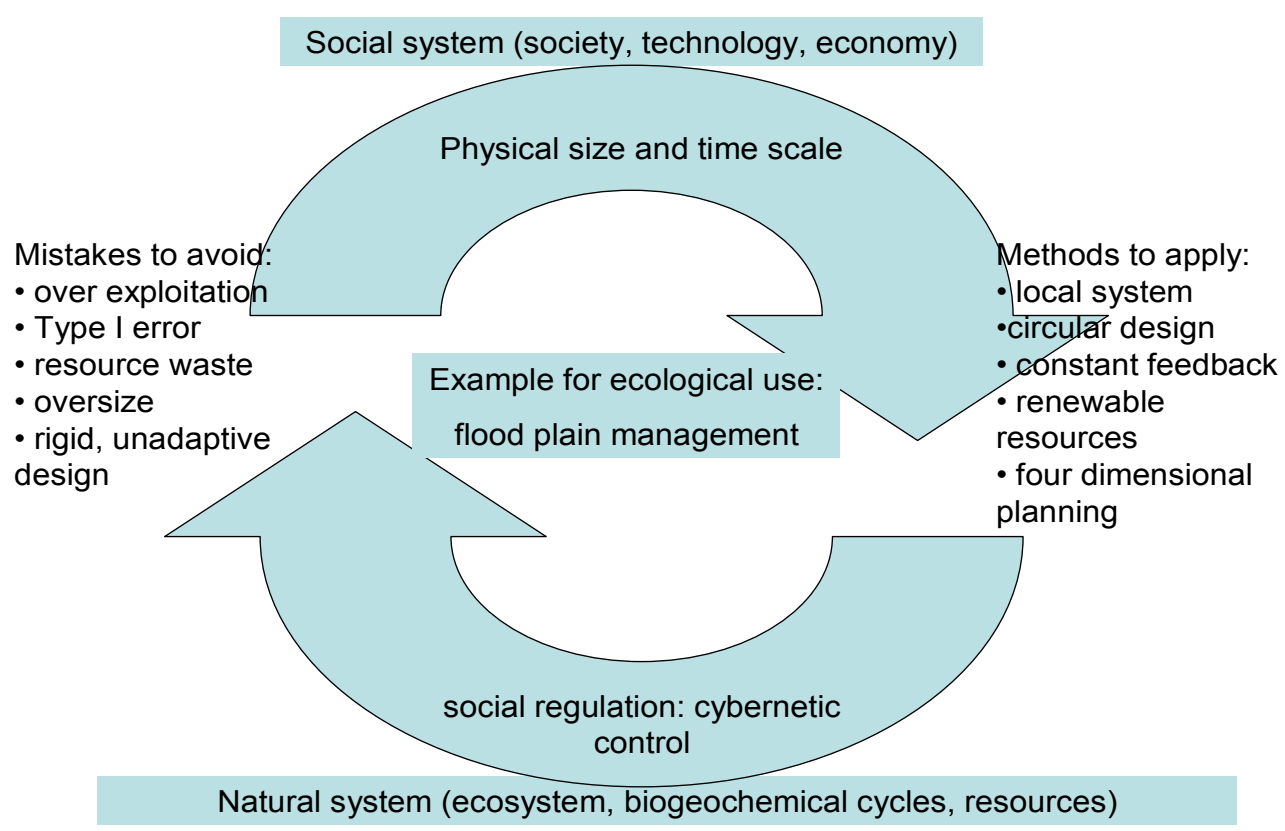

Figure 8. Given certain conditions and provided some strict requirements are met, sustainable river management is possible 
In order to achieve the consistent application of the aforementioned design elements, an additional paradigm shift is necessary in human behaviour. Instead of assuming that what can be done should be done, it has to be realised by all members of society that moral values and standards are objective and compliance with them requires self-discipline, sacrifice and frugality. In other words, societies should be governed by technical and economic self-constraint, the voluntary limitation of production and consumption (Endreffy, 1989). Self constraint, of course, applies to reproduction and population growth rates as well. The difficulties of ecological design arising from deeply rooted technological fundamentalism are discussed in detail by David Orr (2002).

Another problem is inherently dependent on the characteristics of the system to be manipulated. According to a frequently cited claim, hydropower plants are environmentally sound on the basis that they were renewable. However, renewability is merely one aspect of sustainability and hence, the potential to avoid Type one errors. For a start, water itself may be renewable - unless the cycle is disrupted as discussed before - but the structures used to take advantage of its potential are certainly not. Dams cause irreversible changes to a riverine ecosystem if their decommissioning is not solved reassuringly. According to a classification scheme applied to energy generation facilities, the question is whether the non-electric fuel input of the system has active connections with the surrounding environment before use. In this respect water is a fuel having direct, natural relationships with the biosphere and hence, the energy transformation merely consists of the modification of such connections, i.e. the potential energy of water in a certain elevation is used. Yet, in spite of this consideration energy generation from water is ultimately not so good for the environment, because the energy density of water is very low: huge amounts of mass and volume have to be moved before such transformation occurs which most of the time has serious adverse effects on the system as a whole. This is mostly due to the fact that utilisation of such great volumes usually requires profound alterations of the original system design (the river) with an equally expensive price tag in terms of fossil energy (Ferencz, 1989).

\subsection{Examples}

\subsubsection{Floodplain Economy: 'Fok Management' in the Carpathian Basin}

Yet, there are historical and some contemporary examples for the sustainability and frugality principle in river management and design. One of the best known and researched such method is the so called floodplain economy or husbandry, practiced during the Mediaeval Age throughout Europe. In Hungary, both along the Danube (Andrásfaly, 1973) and the Tisza rivers (Molnár, 2002; Fodor, 2002), including their respective tributaries such as the Bodrog (Borsos, 2000), extensive floodplain economy was practiced. The approach applied was to take advantage of the flat natural levees, several metres high and sometimes many hundred metres or even - in the case of major rivers - one or two kilometres wide, built by the rivers on the floodplain during recurrent floods. Water was conducted onto the deeper-lying floodplain areas in small channels with the help of incisions ('fok' in Hungarian), cut into these natural formations. There were also natural gaps where side arms feeding permanent water surfaces in the river valley started. However, most of the smaller foks were human-made or altered and acted as outlets to deep bed canals branching off from the middle-stage water bed of the main channel, where the direction of water flows was dependent on the water level in the main river bed. At high stage water levels the incisions discharged water from the river onto the floodplain thus reducing the vehemence of floods, while upon ebbing the same structures drained floodwater back into the river. The shallow floodplain backswamp ponds and major ox-bow lakes played an important role in the local economy during late Medieval times - in addition to serving as natural water reservoirs. The ecological potential of the floodplains with the help of the foks was utilised with a wide variety of means ranging from fishing, fruit orchards and livestock management to reed harvesting and logging, and, occasionally on the higher elevations, tillage. The channels even provided convenient transport routes for timber, reed and hay, while water flows in them were used by mills (Rácz, 2008).

The spatial structure established in the early middle ages - i.e. livestock husbandry on flood prone lower and crop farming on flood-free higher elevations - was stabilised for centuries and eventual changes in farming practices never affected the natural profile of these two types of terrain. The system was abolished during and after the Ottoman occupation covering the majority of the river floodplains when the incisions and the canals fell in disrepair, were blocked and drained or became waterlogged.

In fact, as it turned out from more recent research, there was a forerunner to the fok system in the Carpathian basin in the form of a centralised canalisation system in the Arpadian era (Takács, 2000, 2003). Historical findings in archives as well as field excavations support the notion that in the $11^{\text {th }}$ and $12^{\text {th }}$ centuries Hungarian kings employed a great amount of manpower to construct a network of canals throughout the riverine plains. This was a sophisticated and highly adaptive water management scheme where - with the help of three parallel canals, higher embankments and occasional sluices in between them - the surrounding terrain could be easily 
and wisely managed as the needs dictated. Water could be evenly distributed on the meadows and pastures from the higher-lying central canal in case of floods so that settlements and crop fields would not be inundated and drained back into the side canals when the flood subsided, but the same canals could also be used for areal irrigation on grazing land or to fill up fish ponds. The densely planted shrubby vegetation on the banks of the central canal was also hedging livestock away and acting as an effective boundary to separate fields of various use from each other.

\subsubsection{Keylines}

A contemporary method of the ingenious canalisation system was invented - or reinvented, rather - on a smaller scale by Yeomans on the other hemisphere, in Australia. He called his structures keylines because the water catchment system was adapted to hilly regions where the water collecting canals run on the contours of the terrain (Yeomans, 1993).

\subsubsection{Mesopotamia}

Irrigation has been a farming practice in many parts of the world for millennia. Maybe the best lesson can be learnt in respect of rivers and sustainable management avoiding Type one errors from the history of irrigation in Mesopotamia. Mesopotamia, the cradle of Western civilisation thanked the potential to develop highly organised hierarchic societies to the invention of irrigation in a semi-arid or arid area. Throughout history, irrigation was practiced here, but on different scales. Local tribes such as the El Shabana have exercised it with modest prudency and this entailed among others fallowing the irrigated land in every alternate year and, eventually, for longer periods of time in order to let the endemic vegetation lower near-surface groundwater table and thus remove accumulated salts (Fernea, 1970). On the other hand, there is much reason to believe that the fall of the Sumerian empire at around $2000 \mathrm{BC}$ was caused by environmental havoc brought about through reckless irrigation and the construction of large-scale structures such as dykes and canals to direct water from the Tigris to the more arid areas around the Euphrates (Adams, 1974).

\subsubsection{Muang Faai}

The traditional Muang Faai water management system in Northern Thailand allows villagers to control the supply of water to their paddy rice fields in ways which are responsive to the needs of individuals and communities. The sophisticated system basically consists of a small reservoir which feeds an intricate, branching network of small channels carrying water in carefully calibrated quantities through clusters of rice terraces in valley bottoms. The system taps into a stream above the highest rice field and when there is enough water, discharges back into the same stream below the lowest lying field. The water in the reservoir at the top is not blocked by an impervious dam, though. It consists of a series of barriers constructed of bunches of bamboo or saplings which allow silt, soil and sand pass through. It is also very flexible, the tops of the barrier are set at the level villagers determine was appropriate for a certain year, so that any excess water immediately passes over the spillway and through the barrier downstream (Tongdeelert \& Lohman, 1991). The ingenious native resource management practices started to deteriorate when administrative units were created in the process of establishing nation states, generally not developed with ecological management in mind. The basic mismatch between government administrative units and watersheds is pervasive at all levels from the most local (Dupar \& Badenoch, 2002) to the international (Badenoch, 2001). Governments have opted instead to create line agencies - departments for forests, water, land and others - that often segregated conservation and development, sometimes within the same agency (Badenoch, 2006).

Note that none of the aforementioned traditional or native water management structures contained any heavy fixed structures and non-renewable system-alien materials such as concrete or steel. When recreated, modern concrete muang faai dams rapidly clog up with silt and debris, requiring special machinery to clean them out. The amount of labour and financial resources needed to maintain such "improved" facilities is often prohibitive and may cause the system to fall into disuse (Tongdeelert \& Lohman, 1991).

\section{Conclusions}

In this paper, the natural behaviour of large rivers was described with the help of system theory. The same approach was used to understand the conflict between the dynamics of river processes and the rigid human made structures imposed on them.

Natural systems maintain a dynamic equilibrium and are seen as an embedded hierarchy of supersystems and subsystems governed by a balanced set of negative and positive feedback loops. The main cause of discrepancies between human made and natural systems lies in the linear logic and the excessive use of external energy of the 
latter. These result in depletion of renewable resources and the need for constant growth at the cost of the finite planet's finite resources. Water use is no exception to this runaway curve.

Rivers are renewable resources of a natural system which is vulnerable, prone to overexploitation and irreversible changes. During centuries of technical operations, rivers were heavily modified in a logic incompatible with the dynamic processes of the natural system. This contradiction led to repeated failures called Type one errors when the human solution to a problem was merely the source of another problem. The natural local water cycle of river basins was first disrupted by deforestation in both the upper catchment and the plains. Later, population pressure and increased flood risk as well as the need for land triggered large-scale river regulation projects shortening river courses and narrowing the floodplain into an artificial floodway. Flood-control works led to unintended consequences such as higher risk of floods, waterlogging and drought, disruption of temporal and spatial patterns and clogging of the floodway. In another round of Type one error humans started to retain water by large dams. They further destroyed the dynamic patterns in the river ecosystem, spoiling groundwater reserves, deteriorating water quality and threatening ecological connections. River restoration efforts try to reverse some of these effects.

All in all, former river management interventions left their heritage on the system which started to behave in an erratic and unpredictable manner. In addition, the time factor became even more stretched and accelerated changes take their toll on the river ecosystem. Sustainable river management systems need to take this into account, leaving ample space and time for the river to behave as it likes. The key objective is to disrupt the positive feedback loop of Type one error. Human-made structures must be designed to provide opportunity for adapting to the ever changing situation resulting from the forces in action in a riverine ecosystem. In the words of the highly honoured Hungarian educator of the $17^{\text {th }}$ century, Comenius: "Omnia sponte fluant, absit violentia rebus", i.e. let everything flow freely, keep away violence from things.

\section{References}

Adams, R. Mc C. (1974). Historic patterns of Mesopotamian irrigation agriculture. In T. Drowning \& G. McGuire (Eds), Irrigation' impact on society. Anthropological papers of the University of Arizona, number 25 (p. 3) Tucson, Arizona: The University of Arizona Press.

Andrásfalvy, B. (1973). A Sárköz és a környező Duna-menti területek ősi ártéri gazdálkodása és vízhasználatai a szabályozás előtt (Ancient floodplain economy and water utilisation schemes in the Sárköz and the neighbouring areas along the Danube river). In Z. Károlyi (Ed.), Vizügyi Történeti Füzetek 6. (Historical Papers on Water Management) Vízdok, Budapest (in Hungarian).

Badenoch, N. (2001). Transboundary Environmental Governance. Washington, DC: World Resources Institute.

Badenoch, N. (2006). Social Networks in Natural Resource Governance in a Multi-Ethnic Watershed of Northern Thailand. A Thesis Submitted for the Degree of Doctor of Area Studies (p. 242). Graduate School of Asian and African Area Studies. Kyoto University.

Balás, D. (2006). Balanced Sustainability In Rural Communities Christelijke Agrarische Hogeschool CAH Dronten Professional Agricultural University Rural Development.

Bertalanffy, L. von. (1968). General System Theory: Foundations, Development, Application. New York: Braziller.

Bodnár, G. (2009). A Tiszába érkező vizekről. A Felső Tisza vízmegtartása (On Waters discharged into the Tisza River - Water retention in the Upper Tisza) Conference presentation at the conference: The Future is in our Hands. All drop of water is a value, Budapest 7th May, 2009.

Borsos, B. P. (2000). Három folyó között. A bodrogközi gazdálkodás alkalmazkodása a természeti viszonyokhoz a folyószabályozási munkák idején (1840-1910). Budapest, Akadémiai Kiadó, 2000 (in Hungarian).

Borsos, B. (1989). A Bös-Visegrád-Nagymarosi vízerömü mint az állatorvosi beteg ló (The Bös-Visegrád-Nagymaros Hydropower Plant as the sick horse of the veterinarian) Presentation at the Ecological Conference of the Danube Circle, Budapest 28-29 January, 1989.

Borsos, B. (2003). Azok a bizonyos könnyü léptek I. Ökológia és rendszerelmélet (Tread Lightly on Earth I. Ecology and Systems Theory) Budapest: L'Harmattan, 251 (in Hungarian).

Borsos, B. (2009). Systems theory and ecological settlement design: a pilot project in rural Hungary. Hungarian Studies (ed. Mihály Szegedy Maszák), Akadémiai Kiadó, Budapest, 23(2), 175-194.

Borsos, B., \& Jan, S. (2013), Integrated Water Resources Management in Hungary. International Journal Of Water Governance, Special Issue on Integrated Water Resources Management - No. 03/04, 379-402. 
Capra, F. (1997). The Web of Life. A new synthesis of mind and matter (p. 320). London: Flamingo.

Chanson, H. (1998). Extreme Reservoir Sedimentation in Australia: a Review. International Journal of Sediment Research, UNESCO-IRTCES, 13(3), 55-63.

Chanson, H., \& James, D. P. (1999). Siltation of Australian Reservoirs: some Observations and Dam Safety Implications. Proc. 28th IAHR Congress, Graz, Austria, Session B5, 6 pages.

Cosgrove, D., \& Petts, G. (1990) Water, engineering and landscape. London: Belhaven Press.

CTGPC. (2007). Annual Report 2007 of the Chinese Three Gorges Project Corporation. Retrieved November 27, 2009, from http://www.ctgpc.com/file/Annual_Report_2007.pdf

Deák, J., László, F., \& Liebe, P. (2001). Changes in the replenishment patterns, flow conditions and quality of underground waters. VITUKI, Hungary, Manuscript.

Dupar, M., \& Nathan, B. (2002). Environment, Livelihoods and Local Institutions: Decentralization in Mainland Montane Southeast Asia. Washington, DC: World Resources Institute.

El-Sayed, S., \& Gert, L. Van D. (1995). The Southeastern Mediterranean Ecosystem Revisited: Thirty Years After the Construction of the Aswan High Dam. Quarterdeck 3.1. Oceanography, Texas A\&M University. Retrieved from http://oceanography.tamu.edu/Quarterdeck/QD3.1/Elsayed/elsayed.html

Endreffy, Z. (1989). Technikai önkorlátozás, mértékletesség, aszkézis (Technical self-constraint, frugality, asceticism). Presentation at the Ecological Conference of the Danube Circle, Budapest 28-29 January, 1989.

ENS. (2003). Environmental News Service May 23, 2003: Louisiana Sinking, One Third of State's Coast Could Vanish By 2050. Lafayette, Louisiana. Retrieved from http://www.ens-newswire.com

Epple, R. (2000). Dam Decommissioning in Europe. The French pilot experiences and the European Context. European Rivers Network. Retrieved December 14, 2009, from http://www.rivernet.org/general/dams/decommissioning/decom3_e.htm\#usa

Ferenczi, C. (1989). A rendszer-környezet kölcsönhatás elemzése energiatermelés esetén és a Bös-Nagymaros-i példa (Analysis of system-environment interactions in the case of energy generation and the example of the Gabcikovo-Nagymaros hydropwer scheme). Presentation at the Ecological Conference of the Danube Circle, Budapest 28-29 January, 1989 (in Hungarian)

Fernea, R. A. (1970). Shaykh and Effendi: Changing Patterns of Authority among the El Shabana of Southern Iraq Cambridge (p. 227). Harvard University Press.

Fodor Z. (2002). A Tisza-menti fokok tájhasznosítási szerepe az újkori folyószabályozások előtt (The role of 'fok' along the Tisza river before river regulations), Falu, Város, Régió, A vidékfejlesztés hírei, 2002/4, pp. 14-17 (in Hungarian).

Frihy, O. E. (2003). The Nile delta-Alexandria coast: vulnerability to sea-level rise, consequences and adaptation. Mitigation and Adaptation Strategies for Global Change, 8(2), 115-138. http://dx.doi.org/10.1023/A:1026015824714

Gartner, J. (2007). Climbers Bring Climate Change from Mountaintop to Laptops. WEST LINN, Oregon, July 31, 2007 (ENS).

Goldsmith, E., \& Hildyard, N. (1984). The Social and Environmental Effects of Large Dams. Wadebridge Ecological Center.

Gregory, K. J. (2006). The human role in changing river channels. Geomorphology, 79, 172-191. http://dx.doi.org/10.1016/j.geomorph.2006.06.018

Gyulai, I. (2009). Fenntartani a fenntarthatatlant (To sustain the unsustainable). In M. Kóródi (ed.), Az erőszak kultúrája. Fenntartható-e a fejlödés? (The Culture of Violence. Can Development be Sustained?) (pp. 135-159). Pallas, Budapest (in Hungarian).

Habersack, H., Piégay, H., \& Rinaldi, M. (2008). Gravel-bed rivers VI - From Process Understanding to River Restoration. Proceedings of the $6^{\text {th }}$ International Gravel-Bed Rivers Workshop, held in Sankt Jakob, Austria, Sept. 5-6, 2005.

Haggett, P. (2001). Geography. A Global Synthesis. Pearson Education Limited, Harlow.

Haskell, D. (2003). Creating a Sustainable Future. Boatman's Quarterly Review, the Journal of Grand Canyon River Guides Inc. Retrieved December 8, 2009, from http://www.gcrg.org/bqr/16-1/future.html 
Hauer, C., Gerald, K., Elisabeth, J., \& Helmut, H. (2009). Floodrisk II - New Strategies for an Integrative Flood Risk Management. The Scientific Scope to find Mutual Solutions in Large River Management and Restoration. Workshop. University of Vienna, Vienna Ecology Centre, Vienna, Austria, 2009 September 7-10.

Horváth, B. (1993). Independence like Hybris. The Correlation of Man and Nature in the Great Hungarian Plain (in Hungarian). Tér és Társadalom, 7(3-4), 105-114 (in Hungarian).

Jungwirth, M., Hohensinner, S., Muhar, S., \& St. Schmutz. (2009). Is scientific knowledge on ecology of large rivers adequately represented in ecology, management and legislation? The Scientific Scope to find Mutual Solutions in Large River Management and Restoration. Workshop. University of Vienna, Vienna Ecology Centre, Vienna, Austria, 2009 September 7-10.

Kajner, P., István, F., Zsuzsa, F., Géza, M., \& Péter, B. (2009). Szelídvízország. Kézikönyv a Tisza-menti ártéri gazdálkodás megalapozásához. [Land of Calm Waters. A Handbook on the Basics of Floodplain Management Farming along the River Tisza.] p. 190.

Koestler, A. (1967). A ghost in the machine. London: Hutchinson \& Co.

Kordina, H., \& Katrina, H. (2004). Flussbauliches Gesamtprojekt Östlich von Wien. Umweltverträglichkeitserklärung. Alternative Lösungsmöglichkeiten - Projektsgeschichte, Alternativen und Varianten, a report commissioned by the Wasserstraßendirektion, Wien (in German).

Korže-Vovk, A., Danilo, K., Andrea, G., Guilio, C., Nicoletta, T., \& Natasa, S. Z. (2009). Review of best practices/guidelines for compensation measures for hydropower generation facilities. Certification for Hydro: Improving Clean Energy project report. Retrieved from http://www.ch2oice.eu/download/public/CH2OICE_D2-2.pdf

Lavergne, M. (1984). The Seven Deadly Sins of Egypt's Aswan High Dam. In E. Goldsmith, \& N. Hildyard (Eds.), The Social and Environmental Effects of Large Dams, 2 (pp. 181-183). Wadebridge Ecological Center.

Lóczy, D. (2007). The changing geomorphology of Danubian floodplains in Hungary. Hrvatski Geografski Glasnik, Zagreb, 69(2), 5-19.

Lovelock, J. (1991). Gaia: The practical science of planetary medicine. London: Gaia Books Ltd.

Lovelock, J. E. ( 1979). Gaia. A new look upon life on Earth. Oxford Univ. Press.

Marten, G. G. (2001). Human Ecology: Basic Concepts for Sustainable Development (p. 238). (London Sterling, VA: Earthscan

McCully, P. (2009). Dam Decommissioning. International Rivers. Retrieved December 14, 2009, from http://www.internationalrivers.org/en/node/571

Meadows, D. H., Meadows, D. L., \& Randers, J. (1992). Beyond the Limits - Confronting Global Collapse and Envisioning a Sustainable Future. (Post Mills, Vermont: Chelsea Green Publishing Company 300).

Meadows, D. H., Meadows, D. L., Randers, J., \& Behrens, W. W. (1972). The Limits to Growth - A Report for the Club of Rome's Project on the Predicament of Mankind. Washington: Potomac Associates. London: Earth Island Ltd.

Meadows, D. H., Randers, J., \& Meadows, D. L. (2004). Limits to Growth - The 30-Year Update. White River Junction, Vermont: Chelsea Green 338.

Mickens, S. (2006). The Colorado river. Student papers in geology, Cochise College Geology Home Page. Retrieved from http://skywalker.cochise.edu/wellerr/students/glg101.htm

Mollison, B. (1988). Permaculture, A Designers' Manual (p. 579). Tyalgum, Australia: Tagari Publications.

Mollison, B. (1990). Permaculture: A Practical Guide for a Sustainable Future. Washington: Island Press.

Molnár, G., \& Pásztor, A. (n.d.). Ártéri tájgazdálkodás a Bodrogközben. Egy mintaprogram tanulságai dióhéjban (Floodplain landscape economy in the Bodrogköz. Lessons from a pilot project in a nutshell), Bokartisz Környezetgazdálkodási és Tájrehabilitációs Közhasznú Társaság (Bokartisz Environmental Management and Landscape Rehabilitation Non Profit Company), Karcsa (in Hungarian).

Morrison, J. I., Sandra, L. P., \& Peter, H. G. (1996). The Sustainable Use of Water in the Lower Colorado River Basin. A joint report of the Pacific Institute and the Global Water Policy Project, November 1996. 
Moser, G. (2007). Sustainable Solutions. Example Wallgauwerk. CIS Workshop: WFD and Hydropower. Berlin, 4 th -5 th June 2007.

NASA Earth Observatory. (2009). Evaporation of the Aral Sea. Retrived December 14, 2009, from http://earthobservatory.nasa.gov/Features/WorldOfChange/aral_sea.php

Neyman, J., \& Pearson, E. S. (1967). 'On the Use and Interpretation of Certain Test Criteria for Purposes of Statistical Inference, Part I', reprinted at 1-66 in Neyman, J. \& Pearson, E.S., Joint Statistical Papers, (Cambridge: Cambridge University Press), 1967 (originally published in 1928).

Novak, B. (2009). May the diversion of the Danube cause environmental damage in the Szigetköz area, Hungary? Geophysical Research Abstracts, Vol. 11, EGU 2009-5088-1, 2009.

Odum, E. P. (1997). Ecology: A Bridge between Science and Society (p. 331). Sunderland, USA: Sinauer Associates Inc.

Odum, H. T. (1994). Ecological and General Systems: An introduction to systems ecology. Colorado: Colorado University Press.

Orr, D. (2002). The Nature of Design: Ecology, Culture, and Human Intention. New York: Oxford University Press.

Ponting, C. (1991). A green history of the world. The environment and the collapse of the great civilisations (p. 430). Sinclair-Stevenson, London.

Postlethwait, J. H., \& Hopson, J. L. (1995). The Nature of Life (p. 935). New York: McGraw-Hill Inc.

Rácz, L. (2008). Magyarország környezettörténete az újkorig (Environmental History of Hungary up to the New Age). MTA Institute for Historical Sciences, Budapest, p. 261 (in Hungarian).

Richter, B. D, Baumgartner, J. V., Wigington, R., \& Braun, D. P. (1997). How Much Water Does a River Need? Freshwater Biology, 37, 231-249. http://dx.doi.org/10.1046/j.1365-2427.1997.00153.x

Richter, B. D., Baumgartner, J. V., Braun, D. P., \& Powell, J. (1998). A Spatial Assessment of Hydrologic Alteration Within a River Network. Regulated Rivers, 14, 329-340. http://dx.doi.org/10.1002/(SICI)1099-1646(199807/08)14:4<329::AID-RRR505>3.0.CO;2-E

Richter, B. D., Baumgartner, J. V., Powell, J., \& Braun, D. P. (1996). A Method for Assessing Hydrologic Alteration Within Ecosystems. $\quad$ Conservation $\quad$ Biology, $\quad 10, \quad 1163-1174$. http://dx.doi.org/10.1046/j.1523-1739.1996.10041163.x

Sale, K. (1991). Dwellers in the Land, The Bioregional Vision (p. 216). New York: New Society Publishers.

Schabuss, M., \& Fritz, S. (2009). The Integrated River Engineering Project (IREP) The Scientific Scope to find Mutual Solutions in Large River Management and Restoration. Workshop. University of Vienna, Vienna Ecology Centre, Vienna, Austria, 2009 September 7-10.

Sheldrake, R. (1987). A New Science of Life. The Hypothesis of Formative Causation (p. 286). London: Paladin Grafton Books.

Takács, K. (2000). Árpád kori csatornarendszerek kutatásáról (On research of canal systems in the Arpadian era) In: R. Várkonyi, Ágnes (ed.): Táj és történelem. Tanulmányok a történeti ökológia világából (Landscape and History. Studies from the World of Historical Ecology). Budapest 2000 pp 73-106 (in Hungarian).

Takács, K. (2003). Medieval Hydraulic Systems in Hungary: Written Sources, Archeaology and Interpreation. In J. Laszlovszky \& P. Szabó (Eds.), People and Nature in Historical Perspective (pp. 289-313), Budapest.

Tenner, E. (1996). Why things bite back. Technology and the revenge of unintended consequences. New York: Vintage Books.

Tongdeelert, C., \& Larry, L. (1991). The muang faai irrigation sytem of Northern Thailand. The Ecologist, 21(2), 101-106.

Townsend, C. R., Harper, J. L., \& Begon, M. (2000). Essentials of Ecology. USA: Blackwell Science.

UNEP. (2007). A Global Outlook for Ice and Snow (p. 238). A report by the United Nations Environment Programme.

UNEP. (2009). Planning and Management of Lakes and Reservoirs: An Integrated Approach to Eutrophication. Newsletter and Technical Publications. Retrieved November 26, 2009, from http://www.unep.or.jp/ietc/Publications/TechPublications/TechPub-11/7-1.asp 
Varela, F., \& Humberto, M. és R. U. (1974). Autopoesis: The Organization of Living Systems, its Characterisation and a Model. BioSystems, 5, 187-196. http://dx.doi.org/10.1016/0303-2647(74)90031-8

VITUKI. (2009). Preliminary Feasibility Study for the Rehabilitation of the Szigetköz Section of the River Danube. Commissioned by the Hungarian Section of the Working Group established by the Government Delegation to the Gabcikovo-Nagymaros Project, February 2009 Manuscript.

WCD. (2000). Dams and Development. A New Framework for Decision Making. The Report of the World Commission of Dams (p. 400). Earthscan Publications UK and USA.

Worster, D. (1984). The Hoover Dam: A Study in Domination. In E. Goldsmith, \& N. Hildyard (Eds.), The Social and Environmental Effects of Large Dams, Vol. 2, Case Studies (pp. 17-24). Wadebridge Ecological Center.

Yeomans, K. (1993). Water for Every Farm. Australia: Griffin Press.

Zolezzi, G., Bellin, A., Bruno, M. C., Maiolini, B., \& Siviglia, A. (2009). Assessing hydrological alterations at multiple temporal scales: Adige River, Italy, Water Resour. Res.

\section{Notes}

Note 1. Read more: http://family.jrank.org/pages/823/Human-Ecology-Theory.html\#ixzz0UqC0OJUK

Note 2. Rodale Institute, Kutztown PA, USA, 1994 personal observation by the author

\section{Copyrights}

Copyright for this article is retained by the author(s), with first publication rights granted to the journal.

This is an open-access article distributed under the terms and conditions of the Creative Commons Attribution license (http://creativecommons.org/licenses/by/3.0/). 